\title{
Pseudomonas aeruginosa bronchopulmonary infection in patients with AIDS, with emphasis on relapsing infection
}

\author{
P. Domingo*, A. Ferré*, M.A. Baraldès*, J. Ris*, F. Sánchez**
}

Pseudomonas aeruginosa bronchopulmonary infection in patients with AIDS, with emphasis on relapsing infection. P. Domingo, A. Ferré, M.A. Baraldès, J. Ris, F. Sánchez. OERS Journals Ltd 1998.

ABSTRACT: The aim of this study was to delineate the clinical and therapeutic characteristics of Pseudomonas aeruginosa bronchopulmonary infection in acquired immunodeficiency syndrome (AIDS) patients.

Eighteen AIDS patients had 39 episodes of $P$. aeruginosa bronchopulmonary infection. Their mean CD4 cell count was $0.012 \pm 0.011$ cells $\times 10^{9} \cdot \mathrm{L}^{-1}$ and two episodes $(5.1 \%)$ occurred in neutropenic patients. Ten patients $(55.5 \%)$ had 21 outbreaks of pseudomonal infection. Relapses were more frequent in patients with chronic bronchitis ( 80 versus $0 \%, p=0.03$ ) and in those who received initial oral antibiotic therapy (100 versus $55.6 \%, p=0.25$ ). Three patients died, but death was directly related to pseudomonal infection in only one patient. In a case-control study, patients with bronchopulmonary $P$. aeruginosa infection had a survival comparable to patients in the control group. Immunoglobulin prophylaxis was administered to three patients with relapses, without success. The two patients who had $P$. aeruginosa eradicated were those who began triple antiretroviral therapy and had a CD4 cell increase $>0.150$ cells $\times 10^{9} \cdot \mathbf{L}^{-1}$.

Relapsing Pseudomonas aeruginosa bronchopulmonary infection affects patients with advanced human immunodeficiency virus infection, prior underlying lung disease, chronic bronchitis and initial oral antibiotic therapy. Immune reconstitution through triple antiretroviral therapy succeeded in eradicating Pseudomonas aeruginosa respiratory infection in two patients.

Eur Respir J 1998; 12: 107-112.
Depts of *Internal Medicine and **Microbiology, Hospital de la Santa Creu i Sant Pau, Universitat Autònoma de Barcelona, Barcelona, Spain.

Correspondence: P. Domingo

Dept of Internal Medicine

Hospital de la Santa Creu i Sant Pau

Avgda. Sant Antoni Ma Claret, 167

08025 Barcelona

Spain

Fax: 3432919269

Keywords: AIDS

Pseudomonas aeruginosa

respiratory infections

Received: September 21997

Accepted after revision March 131998
Bacterial infections have been increasingly recognized as an important cause of morbidity and mortality in human immunodeficiency virus (HIV)-infected patients [1]. The most common causative agents are the encapsulated bacteria, such as Streptococcus pneumoniae and Haemophilus influenzae, but also nontyphi Salmonella, Staphylococcus aureus in the nosocomial setting and Pseudomonas aeruginosa [1, 2]. The 1993 Centers for Disease Control (CDC) classification of HIV infection recognized the increasing importance of bacterial infections in these patients when it considered recurrent bacterial pneumonia as a new acquired immunodeficiency syndrome (AIDS)-defining condition [3].

P. aeruginosa infections in patients with HIV infection have been classically described as late events in the course of the disease and are usually life-threatening and nosocomially acquired, and share many risk factors with patients without HIV infection, such as neutropenia or indwelling venous catheters $[4,5]$. However, the prolonged survival of HIV-infected patients has led to the appearance of novel complications, such as extrapulmonary pneumocystosis or bacillary angiomatosis $[1,6]$. In this setting, a new pattern of pseudomonal infection has emerged in recent years that is characterized by relapsing episodes of community-acquired bronchopulmonary infection, most of them without radiological evidence of pneumonia, a low mor- tality rate and occurrence in the absence of other risk factors for $P$. aeruginosa infection [7, 8].

The present study was undertaken to delineate the clinical and therapeutic features of $P$. aeruginosa bronchopulmonary infections in AIDS patients, with emphasis on the relapsing form of the disease.

\section{Patients and methods}

The study was performed at the AIDS Unit of the Department of Internal Medicine, Hospital de la Santa Creu i Sant Pau (Spain), a 750-bed university hospital, providing care for a population of 1,100 HIV-infected patients. Patients with AIDS who had a bronchopulmonary infection caused by $P$. aeruginosa were prospectively followed from October 1994 to December 1996. The diagnosis was made on the basis of consistent clinical findings with or without radiographic abnormalities. Consistent clinical findings were the new onset of an acute illness with cough producing mucopurulent sputum, breathlessness, ronchi or wheezing, together with systemic features such as fever, leukocytosis, hypoxaemia, significant elevation of the erythrocyte sedimentation rate and C-reactive protein over previous levels, and the isolation of $P$. aeruginosa from sputum or bronchoalveolar lavage (BAL) fluid. To consider the episode attributable to $P$. aeruginosa infection, resolution of 
the clinical picture, laboratory and radiographic abnormalities, where present, with antipseudomonal antibiotics had to occur.

Sputa were routinely cultured for bacteria, mycobacteria, and fungi, whereas respiratory secretion obtained by BAL, were also examined for parasites and early antigen for cytomegalovirus. For BAL specimens, a positive culture was defined by a count of $\breve{S} 10^{5}$ colony forming units. $\mathrm{mL}^{-1}$ of respiratory secretion [9]. A sputum sample was considered suitable for culture when it contained $>25$ leukocytes and $<10$ epithelial cells per low-power field or when the ratio of polymorphonuclear to squamous epithelial cells was Š2:1 [10]. Samples contaminated with oral flora were discarded. A positive sputum culture was considered when $P$. aeruginos $a$ was isolated in abundance [10]. Sensitivity to antibiotics was determined by the KirbyBauer method [11].

Community-acquired disease was defined as that developing in a patient who had not been admitted to a hospital and who had not lived in an institutional setting within the last 60 days. Otherwise, it was considered as nosocomially acquired. Attendance at a day-care centre was considered when the patient visited it at least three times weekly. Prior antimicrobial therapy was considered only when administered within 8 weeks before the diagnosis of the first episode of pseudomonal bronchopulmonary infection. Neutropenia was defined as an absolute neutrophil count $<1.0 \times 10^{9} \cdot \mathrm{L}^{-1}$. Relapse was diagnosed only when there were changing or increasing symptoms, new find- ings on chest radiography and reisolation of $P$ aeruginosa from sputum or BAL fluid cultures. Concurrent sinusitis was diagnosed when there were consistent clinical findings together with paranasal sinus abnormalities on cranial computed tomography (CT) or magnetic resonance imaging (MRI). Respiratory infection-associated bacteraemia was diagnosed when $P$. aeruginosa was isolated simultaneously from respiratory specimens and from blood cultures. To evaluate the impact of relapsing $P$. aeruginosa bronchopulmonary infection on the survival of patients with AIDS, a case-control study was conducted with a control group of 36 patients. The controls were chosen on the basis of CD4 cell count and absence of bronchopulmonary $P$. aeruginosa infection (at least two negative sputum cultures) on a proportion of two controls for each case. Statistical analyses were performed with the StatView 4.5 statistical package (Abacus Concepts, Berkeley, CA, USA). Student's t-test was used to evaluate differences in continuous variables. The Chi-squared test with Yates' correction or Fisher's exact test was used for the comparison of proportions. A value $\mathrm{p}<0.05$ was considered to indicate statistical significance.

\section{Results}

Eighteen patients with AIDS who presented 39 episodes of bronchopulmonary infection caused by $P$. aeruginosa were diagnosed during the study period. There were

Table 1. - Clinical characteristics of human immunodeficiency virus (HIV)-infected patients with Pseudomonas aeruginosa bronchopulmonary infection

\begin{tabular}{|c|c|c|c|c|c|c|c|c|}
\hline Pt. & $\begin{array}{l}\text { Age } \\
\text { yrs }\end{array}$ & Sex & Previous diagnoses & $\begin{array}{l}\text { Prior antimicrobial } \\
\text { therapy }\end{array}$ & $\begin{array}{l}\text { Antiretro- } \\
\text { viral } \\
\text { therapy }\end{array}$ & $\begin{array}{l}\text { PCP } \\
\text { prophy- } \\
\text { laxis }\end{array}$ & $\begin{array}{l}\text { Time since } \\
\text { last hospi- } \\
\text { talization } \\
\text { months }\end{array}$ & $\begin{array}{l}\text { CD cell } \\
\text { count } \\
\mu \mathrm{L}^{-1}\end{array}$ \\
\hline 1 & 33 & $\mathrm{M}$ & PCP, CMV & TMP-SMX, AMX/CLV & ZDV, ddI, ddC & TMP-SMX & 2 & 10 \\
\hline 2 & 36 & M & PCP & Cefixime, clarithromycin & None & PTD & 5 & 1 \\
\hline 3 & 39 & M & $\begin{array}{l}\text { Bacterial pneumonia, } \\
\text { Candida oesophagitis }\end{array}$ & Ceftriaxone & ZDV, ddC & TMP-SMX & 3 & 53 \\
\hline 4 & 26 & $\mathrm{~F}$ & PCP, disseminated MAC & $\begin{array}{l}\text { Clarithromycin, } \\
\text { ethambutol, amikacin }\end{array}$ & ZDV & PTD & 11 & 13 \\
\hline 5 & 31 & M & PCP, CMV & TMP-SMX, AMX/CLV & $\begin{array}{l}\text { ZDV, ddI, } \\
\text { 3TC, PI }\end{array}$ & TMP-SMX & 0 & 8 \\
\hline 6 & 33 & $\mathrm{~F}$ & $\begin{array}{l}\text { Pulmonary tuberculosis, } \\
\text { cryptococcal meningitis }\end{array}$ & $\begin{array}{l}\text { Rifampin, INH, } \\
\text { ceftibuten }\end{array}$ & ZDV, d4T & PTD & 7 & 16 \\
\hline 7 & 32 & $\mathrm{M}$ & $\begin{array}{l}\text { Disseminated MAC, } \\
\text { bacterial pneumonia } \times 2\end{array}$ & $\begin{array}{l}\text { Clarithromycin, } \\
\text { ethambutol, cefotaxime }\end{array}$ & d4T, ddI & TMP-SMX & 2 & 5 \\
\hline 8 & 29 & M & PCP, CMV & Azithromycin & ZDV, ddC, d4T & TMP-SMX & 2 & 20 \\
\hline 9 & 37 & $\mathrm{~F}$ & PCP & TMP-SMX & ZDV, ddC & TMP-SMX & 0 & 10 \\
\hline 10 & 33 & $\mathrm{M}$ & PCP & Ofloxacin & ddI, d4T & PTD & Never & 7 \\
\hline 11 & 27 & $\mathrm{~F}$ & CMV & Ciprofloxacin, AMX/CLV & ddI & PTD & 3 & 14 \\
\hline 12 & 32 & M & CMV, KS & None & ZDV, ddI & TMP-SMX & 2 & 2 \\
\hline 13 & 35 & M & KS, pulmonary tuberculosis & Rifampin, INH, ofloxacin & ddI, d4T & TMP-SMX & 5 & 6 \\
\hline 14 & 36 & M & Pulmonary KS & None & ZDV, ddC & Dapsone & 3 & 2 \\
\hline 15 & 39 & $\mathrm{~F}$ & $\mathrm{PCP} \times 2$ & Ceftriaxone & $\begin{array}{l}\text { ZDV, ddI, } \\
\text { 3TC, PI }\end{array}$ & TMP-SMX & 2 & 8 \\
\hline 16 & 37 & M & $\begin{array}{l}\text { NHL, disseminated } \\
\text { tuberculosis, bacterial } \\
\text { pneumonia }\end{array}$ & $\begin{array}{l}\text { Rifampin, INH, } \\
\text { ethambutol, pyrazinamide, } \\
\text { ceftriaxone }\end{array}$ & ZDV, ddC & PTD & 0 & 5 \\
\hline 17 & 36 & M & PCP, CMV & Ofloxacin, azithromycin & ZDV, ddI, d4T & PTD & 4 & 18 \\
\hline 18 & 33 & M & $\begin{array}{l}\mathrm{PCP} \times 3 \text {, disseminated } \\
\text { tuberculosis }\end{array}$ & $\begin{array}{l}\text { Rifampin, INH, TMP- } \\
\text { SMX, cefotaxime }\end{array}$ & $\mathrm{ddI}, 4 \mathrm{dT}$ & TMX-SMX & 2 & 16 \\
\hline
\end{tabular}

Pt.: patient; M: male; F: female; PCP: Pneumocystis carinii pneumonia; CMV: cytomegalovirus; MAC: Mycobacterium avium complex; KS: Kaposi's sarcoma; NHL: non-Hodgkin lymphoma; TMP-SMX: cotrimoxazole; AMX/CLV: amoxycillin/clavulanate; INH: isoniazid; ZDV: zidovudine; ddI: didanosine; ddC: zalcitabine; 3TC: lamivudine; PI: protease inhibitor; d4T: stavudine; PTD: aerosolized pentamidine. 
13 males $(72.2 \%)$ and five females $(27.8 \%)$ with a mean age of 33.6 \pm 3.7 yrs (range: $26-39$ yrs). Fifteen patients $(83 \%)$ were smokers and eight of them met the criteria for chronic bronchitis. Thirteen patients $(72.2 \%)$ had been drug misusers, three $(16.7 \%)$ were homosexuals and two $(11.1 \%)$ heterosexuals. Nine patients $(50 \%)$ had been admitted to the hospital within the 60 days before the diagnosis of the first episode, whereas seven $(38.9 \%)$ regularly attended the day-care facilities. All of the patients met the 1993 CDC definition of AIDS and 16 of them (88.9\%) had met it for more than $1 \mathrm{yr}$. They represented $3.4 \%$ of all the patients diagnosed with AIDS at the hospital. Most of them had AIDS diagnosed on the basis of opportunistic infections, mainly Pneumocystis carinii pneumonia (PCP) (table 1$)$. Sixteen patients $(88.9 \%)$ had suffered prior nonpseudomonal respiratory infections and had received broadspectrum antibiotic therapy (table 1). Seven patients $(38.9 \%)$ were receiving anti-PCP prophylaxis with aerosolized pentamidine, whereas $10(62 \%)$ were receiving cotrimoxazole. Ten patients $(55.5 \%)$ had a permanent venous infusion port implanted. Four patients $(22.2 \%)$ had received cytotoxic chemotherapy. Only one patient $(5.5 \%)$ had sinusitis concurrently with bronchitis. The mean CD4 cell count was $0.012 \pm 0.011$ cells $\times 10^{9} \cdot \mathrm{L}^{-1}$ (range: $0.001-$ 0.053 ) and the mean neutrophil count was $2.1 \pm 1.5 \times 10^{9} \cdot \mathrm{L}^{-1}$ (range: $\left.0.2-7.010^{9} \cdot \mathrm{L}^{-1}\right)$. Only two episodes $(9.6 \%)$ occurred when the patients were neutropenic. Blood cultures were positive in only two episodes $(9.6 \%)$. Cough productive of purulent sputum and fever dominated the clinical picture (table 2). The chest radiograph disclosed abnormalities in 15 episodes (38\%) (table 2). When present, the radiographic abnormality was usually focal airspace consolidation. Five patients had chest CT scans performed, which showed bronchiectasis in four of them, whereas there were no abnormalities in the other patient. Ten pat- ients $(55.5 \%)$ had between 1-6 relapses, with symptomfree periods ranging from 1-8 months. Relapses had a stereotypical indolent clinical presentation similar to the initial episode. P. aeruginosa was isolated from respiratory secretions in pure growth in 33 out of 39 episodes (84.6\%). In the other six episodes, it was isolated together with $P$. carinii (two), methycillin-resistant $S$. aureus, Mycobacterium tuberculosis, Mycobacterium simiae and Aspergillus spp. Ten out of 39 pseudomonal isolates $(28 \%)$ were resistant to ceftazidime, 15 to imipenem (39\%), 4 to amikacin $(11 \%), 18(45 \%)$ to quinolones and $19(48 \%)$ to aztreonam.

Six patients $(33.3 \%)$ were treated initially with oral antibiotics, whereas $12(66.7 \%)$ received i.v. antibiotic therapy (table 3). In all of the patients, antibiotic therapy was adjusted on the basis of antibiotic susceptibility results. Most of the relapses were treated with home antibiotic therapy, especially when a venous infusion port was available. In three out of 10 patients $(30 \%)$ who received quinolones and a carbapenem, resistant strains appeared during treatment. No other bronchopulmonary infection was documented during the follow-up among these patients. Five patients received immunoglobulins $(200 \mathrm{mg}$. $\mathrm{kg}^{-1}$ on a monthly basis), but this prophylactic measure could be evaluated only in three patients (numbers 5, 15 and 18) who took it for Š 2 months. Unfortunately, these three patients continued to present outbreaks of pseudomonal infection despite the administration of immunoglobulins. There were no statistically significant differences between patients who had or did not have relapses with respect to age, sex, prior lung disease, prior hospitalization, site of acquisition, air-space consolidation on chest radiography, and CD4 and neutrophil counts. The presence of chronic bronchitis was significantly more frequent in patients who presented relapses ( 80 versus $0 \%, \mathrm{p}=0.03$ ).

Table 2. - Clinical presentation of human immunodeficiency virus (HIV)-infected patients with Pseudomonas aeruginosa bronchopulmonary infection

\begin{tabular}{|c|c|c|c|c|c|}
\hline Patient & Acquisition & $\begin{array}{l}\text { Symptoms } \\
\text { (duration days) }\end{array}$ & $\begin{array}{l}\text { Isolation of } \\
\text { P. aeruginosa }\end{array}$ & Chest radiography & $\begin{array}{l}\text { Neutrophil } \\
\text { count } \times 10^{9} \cdot \mathrm{L}^{-1}\end{array}$ \\
\hline 1 & Nosocomial & Cough, increased sputum (2) & Sputum & Negative & 4.2 \\
\hline 2 & Community & Cough, increased sputum (5) & Sputum & Bilateral diffuse interstitial disease & 1.1 \\
\hline 3 & Community & Cough, increased sputum (4) & $\begin{array}{l}\text { Sputum, BAL, } \\
\text { blood }\end{array}$ & LLL airspace disease & 0.7 \\
\hline 4 & Community & Cough, chest pain, dyspnoea (1) & BAL & $\begin{array}{l}\text { Right middle lobe airspace } \\
\text { disease }\end{array}$ & 7.0 \\
\hline 5 & Nosocomial & $\begin{array}{l}\text { Cough, increased sputum, } \\
\text { dyspnoea (7) }\end{array}$ & Sputum & Negative & 2.5 \\
\hline 6 & Community & Cough, increased sputum (12) & Sputum & Negative & 1.8 \\
\hline 7 & Nosocomial & Cough, increased sputum (14) & Sputum & Negative & 1.5 \\
\hline 8 & Nosocomial & Cough, dyspnoea, wheezing (2) & BAL & $\begin{array}{l}\text { RUL, RML and LLL airspace } \\
\text { disease }\end{array}$ & 1.4 \\
\hline 9 & Nosocomial & Cough, increased sputum (3) & BAL, blood & RUL disease & 0.2 \\
\hline 10 & Community & $\begin{array}{l}\text { Cough, increased sputum, } \\
\text { chest pain (1) }\end{array}$ & Sputum, BAL & LLL airspace disease & 1.2 \\
\hline 11 & Community & Cough, increased sputum (5) & Sputum & Bilateral diffuse interstitial disease & 2.4 \\
\hline 12 & Nosocomial & Cough, increased sputum (8) & Sputum & Negative & 2.8 \\
\hline 13 & Community & Cough, chest pain, fever (1) & Sputum & Negative & 1.5 \\
\hline 14 & Community & $\begin{array}{l}\text { Cough, chest pain, dyspnoea, } \\
\text { wheezing (1) }\end{array}$ & Sputum & Negative & 2.3 \\
\hline 15 & Nosocomial & Cough, increased sputum (3) & BAL & LLL airspace disease & 1.5 \\
\hline 16 & Nosocomial & Cough, increased sputum (3) & Sputum & Negative & 1.1 \\
\hline 17 & Community & Cough, increased sputum (4) & Sputum & Negative & 1.3 \\
\hline 18 & Nosocomial & Cough, increased sputum (7) & Sputum & Bilateral diffuse interstitial disease & 2.9 \\
\hline
\end{tabular}

BAL: bronchoalveolar lavage; LLL: left lower lobe; RUL: right upper lobe; RML: right middle lobe. 
Table 3. - Treatment and outcome of human immunodeficiency virus (HIV)-infected patients with Pseudomonas aeruginosa bronchopulmonary infection

\begin{tabular}{|c|c|c|c|}
\hline Patient & Therapy & Outcome & Follow-up \\
\hline 1 & $\begin{array}{l}\text { i.v. ceftazidime for } 10 \text { days, then oral } \\
\text { ofloxacin for } 5 \text { days }\end{array}$ & Recovered & Relapsed with bronchitis \\
\hline 2 & $\begin{array}{l}\text { i.v. ceftazidime for } 7 \text { days, then oral } \\
\text { ciprofloxacin for } 7 \text { days }\end{array}$ & Recovered & No relapses \\
\hline 3 & i.v. aztreonam for 1 day & Died with septic shock & \\
\hline 4 & $\begin{array}{l}\text { i.v. imipenem for } 3 \text { days, then oral } \\
\text { ciprofloxacin }\end{array}$ & Recovered & Relapsed with pneumonia $\times 2$ \\
\hline 5 & Oral ciprofloxacin for 12 days & Recovered & $\begin{array}{l}\text { Relapsed with bronchitis } \times 6 \text { immunoglobulin } \\
\text { therapy. No relapses after starting triple ARV } \\
\text { therapy }\end{array}$ \\
\hline 6 & Oral ofloxacin for 14 days & Recovered & Relapsed with bronchitis \\
\hline 7 & $\begin{array}{l}\text { i.v. meropenem for } 5 \text { days then oral } \\
\text { ofloxacin for } 7 \text { days }\end{array}$ & Recovered & No relapses \\
\hline 8 & i.v. ceftazidime for 10 days & Recovered & Relapsed with pneumonia \\
\hline 9 & $\begin{array}{l}\text { i.v. ceftazidime for } 4 \text { days, then oral } \\
\text { ofloxacin for } 10 \text { days }\end{array}$ & Recovered & Relapsed with pneumonia \\
\hline 10 & Oral ofloxacin for 14 days & Recovered & Relapsed with pneumonia \\
\hline 11 & i.v. meropenem for 10 days & Recovered & Lost to follow-up \\
\hline 12 & i.v. ceftazidime for 10 days & Recovered & No relapses \\
\hline 13 & Oral ofloxacin for 14 days & Recovered & Relapsed with bronchitis $\times 2$ \\
\hline 14 & Oral ciprofloxacin for 4 days & $\begin{array}{l}\text { Died of pulmonary } \\
\text { Kaposi's sarcoma }\end{array}$ & \\
\hline 15 & i.v. cefepime for 10 days & Recovered & $\begin{array}{l}\text { Relapsed with pneumonia. Relapsed with bron- } \\
\text { chitis } \times 2 \text {. Immunoglobulin therapy. No } \\
\text { relapses after starting triple ARV therapy }\end{array}$ \\
\hline 16 & i.v. ceftazidime for 2 days & Died of NHL & \\
\hline 17 & i.v. meropenem for 10 days & Recovered & No relapses \\
\hline 18 & Oral ciprofloxacin for 12 days & Recovered & $\begin{array}{l}\text { Relapsed with bronchitis } \times 3 \text {. Immunoglobulin } \\
\text { therapy }\end{array}$ \\
\hline
\end{tabular}

NHL: non-Hodgkin lymphoma; ARV: antiretroviral.

Relapses tended to occur more frequently in patients initially treated with oral antibiotics than in those treated with $i . v$. antibiotic therapy (100 versus $55.6 \%, \mathrm{p}=0.25$ ).

Three patients died during an episode of bronchopulmonary infection but only one death $(2.5 \%)$ was directly attributable to the pseudomonal infection, in one of the two neutropenic patients who had a positive blood culture. Of the 12 patients who died during the follow-up, none had, death related to $P$. aeruginosa infection. The mean survival from the first episode of infection was 4.5 \pm 3.9 months (range: 1-10 months), whereas patients in the control group had a mean survival of 5.5 \pm 2.7 months (range: $1-11$ months) ( $\mathrm{p}=0.33$ ). One patient was lost during follow-up and the other two patients are still alive. They began triple antiretroviral therapy, including an HIV-protease inhibitor, in October 1996. Since then, they have not experienced any new relapse. This has occurred simultaneously with a dramatic decrease in viral load and an increase in CD4 cell count superior to $>0.150 \times 10^{9} \cdot \mathrm{L}^{-1}$ in both patients. Follow-up sputum cultures have been repeatedly negative for $P$. aeruginosa.

\section{Discussion}

Relapsing bronchopulmonary $P$. aeruginosa infections in advanced HIV-infected patients constitute a distinct syndrome [7, 8]. Typically, the patient has local predisposing conditions such as prior lung damage caused by opportunistic infections that eventually lead to the appear- ance of bronchiectasis or bullae. Usually, the patients have also been exposed to repeated courses of broad-spectrum antibiotics because of previous respiratory infections. Most of these circumstances were present in our patients. All but one had had serious pulmonary infections and most of them had received repeated courses of broad-spectrum antibiotics in the past, mostly cotrimoxazole, amoxicillin/ clavulanate and second- and third-generation cephalosporins. This may have exerted a selective pressure over bronchial flora and thus may have led to infection with $P$. aeruginosa. Most of the patients were on PCP prophylaxis with cotrimoxazole, which is not active against $P$. aeruginosa.

Some authors have suggested that HIV-infected patients may acquire Pseudomonas infection by colonization via nebulized pentamidine [2]. Although nebulizers are a well-recognized source of Pseudomonas colonization in the upper airway, more than half of the episodes of pseudomonal bronchopulmonary infection reported herein affected patients who were on cotrimoxazole prophylaxis. This strongly argues against the acquisition of Pseudomonas by this route.

From a clinical point of view, the diagnosis is suggested by subacute or chronic bronchitis or, less frequently, pneumonia. In most patients the clinical picture is not indicative of pseudomonal infection, and if sputum cultures are not routinely taken, this diagnosis may be delayed or even overlooked. Subacute bronchitis or pneumonia in an advanced HIV-infected patient which fails to be resolved with 
standard antibiotic therapy should raise, among others, the suspicion of $P$. aeruginosa bronchopulmonary infection $[7,8]$. Fortunately, the usually overall low mortality of this infection makes decision about treatment not immediately urgent. It has been suggested that pseudomonal sinus disease can act as a nidus for infection, although the relative frequency of sinusitis among patients with pseudomonal bronchopulmonary infection has ranged from 6-60\% [7, 8]. Concurrent sinusitis was found in only $5.5 \%$ of our patients.

The episodes of pseudomonal bronchopulmonary infection usually respond well to antipseudomonal antibiotics, although recurrence is very frequent. A characteristic of the strains isolated from patients in the present study is the high degree of resistance to antipseudomonal antibiotics. However, this may be explained by the adaptive resistance by $P$. aeruginosa strains under great antibiotic selective pressure [12]. Relapse of pseudomonal infections among AIDS patients seem to be related to the initial choice of antipseudomonal therapy, as it has been suggested that administration of oral agents or i.v. antibiotics for $<14$ days represents suboptimal therapy [7]. Two risk factors predisposing to relapses were identified: the presence of chronic bronchitis and initial oral antibiotic therapy. In spite of adequate $i . v$. antibiotic therapy in most initial episodes or relapses, persistent colonization by Pseudomonas develops in a significant proportion of patients with intermittent outbreaks of bronchopulmonary infection similar to those observed in individuals with cystic fibrosis. As with these individuals, maintenance with aerosolized aminoglycosides has been tested successfully in anecdotal reports [13-15]. Long-term maintenance antipseudomonal therapy might be indicated in patients with relapsing infection, since this form of therapeutic intervention has been shown to reduce the frequency and severity of recurrent infection in patients with cystic fibrosis [16]. It is possible that, as with cystic fibrosis, the vicious circle of chronic bacterial endobronchitis damages the airways and results in progressive bronchiectasis, as documented in some of our patients [15].

It has been demonstrated that, particularly in the advanced stages of HIV infection, a significant impairment of B cell activation occurs, predominantly affecting the synthesis of immunoglobulin (Ig)M [17]. Both the T-cellindependent and T-cell-dependent differentiation of $\mathrm{B}$ cells is impaired, resulting in a decreased specific humoral res-ponse to various, notably bacterial, antigens. In addition, polyclonal B cell activation has been observed, which re-sults in polyclonal hypergammaglobulinaemia, and primarily involves the synthesis of $\operatorname{IgG}$ and $\operatorname{IgA}$ [18]. In HIV-infected children and adults with recurrent bacterial infections, particularly those affecting the respiratory system, the administration of i.v. immunoglobulins has been helpful in preventing relapses of infection [19-21]. Among the patients reported, there were a few in whom $P$. aeruginosa infection was prevented [19-21]. The role of i.v. immunoglobulins in patients with pseudomonal infections has yet not been established, but, in view of its success in preventing other bacterial infections [19-21], a trial may be reasonable. Intravenous immunoglobulins were administered in five patients with two or more episodes of $P$. aeruginosa bronchopulmonary infection and, in the three who could be evaluated, this treatment did not prevent relapse.
The prolonged survival in the face of severe immunosuppression in HIV-infected patients is probably the most important factor in the development of Pseudomonas infection. The current patients were all late in the course of HIV infection, as demonstrated by severely depressed CD4 counts and the short survival time. Reconstitution of the immune system seems of paramount importance to avoid relapses of $P$. aeruginosa infection. Fortunately, this can be accomplished, at least theoretically, with triple antiretroviral therapy including HIV-protease inhibitors [22]. This treatment has been associated with remission of opportunistic infections and Kaposi's sarcoma [23, 24]. In two of the survivors of the present series who were able to begin triple antiretroviral therapy CD4 counts have substantially increased, and no further episode of pseudomonal infection has been documented after 15 months of follow-up (unpublished observation). In addition, similarly to what has occurred with other opportunistic infections [23], no cases of relapsing $P$. aeruginosa bronchopulmonary infection have been observed among our patients since the generalization of triple antiretroviral therapy, i.e. in the last 15 months. Thus, the universal use of the new antiretroviral regimens [22] may improve the immune status of advanced HIV-infected patients and eventually diminish infections such as relapsing pseudomonal bronchopulmonary infections.

In summary, relapsing Pseudomonas aeruginosa bronchopulmonary infections are characteristic of advanced human immunodeficiency virus disease with prior lung damage. There has been no effective therapeutic or prophylactic regime to avoid relapses to date. However, immune reconstitution with triple antiretroviral regimen has proved useful in a limited number of our patients. Although no definite conclusion can be drawn from our limited experience, high-potency antiretroviral therapy seems the best option to prevent the appearance of this infection or to control it, together with antipseudomonal antibiotics, once it has appeared.

\section{References}

1. Berger BJ, Hussain F, Roistacher K. Bacterial infections in HIV-infected patients. Infect Dis Clin N Am 1994; 8: 449-465.

2. Schuster MG, Norris AH. Community-acquired Pseudomonas aeruginosa pneumonia in patients with HIV infection. AIDS 1994; 8: 1437-1441.

3. Centers for Disease Control. 1993 Revised classification system for HIV infection and expanded surveillance case definition for AIDS among adolescents and adults. MMWR 1992; 41: No. RR-17, 1-19.

4. Dropulic LK, Leslie JM, Eldred LJ, Zenilman J, Sears CL. Clinical manifestations and risk factors of Pseudomonas aeruginosa infection in patients with AIDS. $J$ Infect Dis 1995; 171: 930-937.

5. Fichtenbaum CJ, Woeltje KF, Powderly WG. Serious Pseudomonas aeruginosa infections in patients infected with human immunodeficiency virus: a case-control study. Clin Infect Dis 1994; 19: 417-422.

6. Raviglione MC. Extrapulmonary pneumocystosis: the first 50 cases. Rev Infect Dis 1990; 12: 1127-1138.

7. Baron AD, Hollander H. Pseudomonas aeruginosa bronchopulmonary infection in late human immunodeficiency virus disease. Am Rev Respir Dis 1993; 148: 992-996. 
8. Ali NJ, Kessel D, Miller RF. Bronchopulmonary infection with Pseudomonas aeruginosa in patients infected with human immunodeficiency virus. Genitourin Med 1995; 71: 73-77.

9. Baselski VS. Practical laboratory guidelines for performing respiratory cultures on patients with ventilatorassociated pneumonia. Clin Microbiol Newslett 1994; 16: 65-69.

10. Pezzlo M. Specimen acceptability: evaluation of specimen quality. In: Isenberg HD, ed. Clinical Microbiology Procedures Handbook. Washington, DC, American Society for Microbiology, 1995; pp. 1.3.1-1.3.6.

11. National Committee for Clinical Laboratory Standards. Performance standards for antimicrobial disk susceptibility tests, 5th Edn; Approved Standard. Villanova, PA, NCCLS. Document M2-A5 (ISBN 1-56238-208-X), 1993.

12. Barclay ML, Begg EJ, Chambers ST, Thornley PE, Pattemore PK, Grimwood K. Adaptive resistance to tobramycin in Pseudomonas aeruginosa lung infection in cystic fibrosis. J Antimicrob Chemother 1996; 37: 1155-1164.

13. Ainsworth JG, Mitchell D, Harris JR. Successful prevention of recurrent pneumonia caused by Pseudomonas aeruginosa in a patient with AIDS. Int J STD AIDS 1995; 6: 123-124.

14. Green ST, Nathwani D, Gourlay Y, McMenamin J, Goldberg DJ, Kennedy DH. Nebulized colistin (polymyxin E) for AIDS-associated Pseudomonas aeruginosa pneumonia. Int J STD AIDS 1992; 3: 130-131.

15. Ramsey BW. Management of pulmonary disease in patients with cystic fibrosis. N Engl J Med 1996; 335: 179188.

16. Hodson ME, Penketh RA, Batten JC. Aerosol carbenicillin and gentamicin treatment of Pseudomonas aeruginosa infection in patients with cystic fibrosis. Lancet 1981; 2: $1137-1139$.
17. Fauci AS, Pantaleo G, Stanley S, Weissman D. Immunopathogenic mechanisms of HIV infection. Ann Intern Med 1996; 124: 654-663.

18. Lane HC, Depper JM, Greene WC, Whalen G, Waldmann TA, Fauci AS. Qualitative analysis of immune function in patients with the acquired immunodeficiency syndrome. Evidence for a selective defect in soluble antigen recognition. N Engl J Med 1985; 313: 79-84.

19. National Institute of Child Health and Human Development Intravenous Immunoglobulin Study Group. Intravenous immune globulin for the prevention of bacterial infections in children with symptomatic human immunodeficiency virus infection. $N$ Engl J Med 1991; 325: 7380.

20. Spector SA, Gelber RD, McGrath N, et al. A controlled trial of intravenous immune globulin for the prevention of serious bacterial infections in children receiving zidovudine for advanced human immunodeficiency virus infection. N Engl J Med 1994; 331: 1181-1187.

21. Kiehl MG, Stoll R, Broder M, Mueller C, Foerster ECh, Domschke W. A controlled trial of intravenous immune globulin for the prevention of serious infections in adults with advanced human immunodeficiency virus infection. Arch Intern Med 1996; 156: 2545-2550.

22. Carpenter ChCJ, Fischl MA, Hammer SM, et al. Antiretroviral therapy for HIV infection in 1997. Updated recommendations of the International AIDS Society-USA Panel. JAMA 1997; 277: 1962-1969.

23. Domingo P, Guardiola JM, Iranzo A, Margall N. Remission of progressive multifocal leukoencephalopathy after antiretroviral therapy. Lancet 1997; 349: 1554-1555.

24. Murphy M, Armstrong D, Sepkowitz KA, Ahkami RN, Myskowski PI. Regression of AIDS-related Kaposi's sarcoma following treatment with an HIV-1 protease inhibitor. AIDS 1997; 11: 261-262. 